\title{
Performance of Japanese Quails Fed Feeds Containing Different Corn and Limestone Particle Sizes*
}

- Author(s)
Berto DA 1
Garcia EA ${ }^{2}$
Móri $\mathrm{C}^{3}$
Faitarone $\mathrm{ABG}^{3}$
Pelícia $\mathrm{K}^{3}$
Molino AB

1 Student of the Post-Graduation Program in
Animal Science (M.SC.), FMVZ, UNESP/
Botucatu. Grant FAPESP, process n. 04/
O3566-6
2 Associate Professor of the Animal Production
Department, FMVZ, UNESP/Botucatu
3 Students of the Post-Graduation Program
in Animal Science (Ph.D.), FMVZ, UNESP/
Botucatu
4 Under-graduate student of Animal Science,
FMVZ, UNESP/Botucatu
* Project funded by FAPESP

Mail Address

Edivaldo Antonio Garcia

Depto de produção Animal, FMVZ/UNESP

Fazenda Lageado, $\mathrm{s} / \mathrm{n}^{\circ}$

18.610-000. Botucatu, SP, Brasil

E-mail: egarcia@fca.unesp.br

\section{Keywords}

Corn, egg quality, geometrical diameter, Imestone, performance.

\section{ABSTRACT}

This study aimed at evaluating performance and egg quality of Japanese quails fed feeds containing different corn and limestone particle sizes. A total number of 648 birds in the peak of production was distributed in a random complete block experimental design, using a 2x3 factorial arrangement (2 corn particle sizes and 3 limestone particle sizes). Birds were designated to one of two blocks, with six replicates of 18 birds each. Mean geometric diameter (MGD) values used were $0.617 \mathrm{~mm}$ and $0.723 \mathrm{~mm}$ (corn fine and coarse particle sizes, respectively), and $0.361 \mathrm{~mm}, 0.721 \mathrm{~mm}$, and $0.947 \mathrm{~mm}$ (limestone fine, intermediate and coarse particle sizes, respectively). The following treatments were applied: T1: fine corn feed, with 100\% fine limestone; T2: fine corn feed, with $50 \%$ fine limestone and $50 \%$ intermediate limestone; T3: fine corn feed, with 50\% fine limestone and 50\% coarse limestone; T4: coarse corn feed, with 100\% fine limestone; T5: coarse corn feed, with $50 \%$ fine limestone and $50 \%$ intermediate limestone; T6: coarse corn feed, with $50 \%$ fine limestone and $50 \%$ coarse limestone. The experiment lasted 112 days, consisting of 4 cycles of 28 days. No significant interaction was observed among corn and limestone particle sizes for any of the analyzed parameters. There were no significant effects $(p>0.05)$ of the tested corn particle sizes on quail performance or egg quality. There were significant $(p<0.05)$ isolated effects of limestone particle size only on the percentage of cracked eggs, which was reduced when birds fed $50 \%$ coarse limestone $(0.947 \mathrm{~mm})$ and $50 \%$ fine limestone $(0.361 \mathrm{~mm})$ as compared to those fed $100 \%$ fine limestone. Therefore, the inclusion of $50 \%$ coarse limestone $(0.947 \mathrm{~mm})$ is recommended for quail egg production.

\section{INTRODUCTION}

The optimization of egg production and quality potential of poultry is associated to several factors, such as proper environmental conditions, health, genetic improvement, and supply of adequate feeds.

Feed ingredient particle size assessment is included in this context, as, regardless the rearing phase, diets can be fed in mesh, crumbled, or pelleted form. This requires ingredient grinding, and particle size determination. Mill screen diameter is related to ground particle size, which may cause performance variation (De Brum et al., 1998). The most precise parameter to evaluate particle size is MGD (mean geometric diameter) of the particles, which can be determined in the laboratory.

Many research studies were carried out aiming at determining ideal particle size of feed ingredients, such as corn and limestone (Freitas et al., 2002; Leandro et al., 2001; Magro et al., 1999). The correct determination of corn particle size is important, because it implies in 
the possibility of increasing animal productivity, obtained through better feed intake, weight gain, egg production, egg weight, and feed conversion ratio.

Calcium, due to its relevance in eggshell formation, has been extensively studied (Ito, 2002; Scheideler, 1998; Guinotte and Nys, 1991; Roland, 1986). In layer production, significant direct economic losses are caused by low eggshell quality and cracked eggs rates.

Most research studies on calcium investigate the most appropriate levels to be fed to poultry, as well as optimal limestone particle size. Variations in these factors may influence egg production and quality.

When limestone presents a very fine particle size, its transit through the gizzard is very fast and therefore present low availability at the time of eggshell formation (Zhang \& Coon, 1997). According to Coon (2002), $1 / 3$ or $1 / 2$ of the supplied limestone supplied to commercial layers should be coarse, with a diameter higher than $1.0 \mathrm{~mm}(2.5 \mathrm{~mm}$ average diameter).

In layers, eggshell formation usually occurs during the night, when there birds present low feed intake. The use of coarse particles of calcium ensure a longer retention of these particles in the gizzard, and their longer permanence in the intestinal tract, thereby increasing calcium availability at the time of egg formation. This reduces the mobilization of bone calcium by the birds, which also benefits eggshell quality, as eggshells containing high bone calcium usually present quality problems, according to Famer et al. (1986).

However, in Japanese quails, due to body size differences, it may not be valid to extrapolate results obtained in corn and limestone particle sizes performed with layer chickens or broilers. In addition, the small amount of information in literature on this subject demand further studies.

This study aimed at investigating the influence of different dietary corn and limestone particle sizes on the performance and egg quality of Japanese quails, aiming at obtaining the best MGD values to optimize Japanese quail egg production and quality.

\section{MATERIALS AND METHODS}

The experiment was carried out in the Poultry Production Sector of the School of Animal and Veterinary Sciences - UNESP/Botucatu. The experimental period lasted 112 days, consisting of 4 cycles of 28 days each. A random complete block experimental design, with a $2 \times 3$ factorial arrangement ( 2 corn particle sizes and 3 limestone particle sizes), was applied. A total number of 648 birds in the peak of production was distributed in two blocks, with six replicates of 18 birds each.

Birds were housed in a $15 \mathrm{~m}$ long $\times 7 \mathrm{~m}$ wide poultry house, containing $96 \mathrm{~cm}$ long $\times 33 \mathrm{~cm}$ wide $\times 16 \mathrm{~cm}$ high metal cages, specific for egg production. Cages, with a capacity of 18 birds each, were divided in three compartments. Each compartment was equipped with 1 nipple drinker and 1 trough feeder located in front of the cage. Birds were acquired with one day of age, and raised under the same management and feeding conditions until the onset of lay. Light was provided 17 hours per day. Birds were offered feed and water ad libitum during the entire experimental period, and feed was supplied twice daily to each experimental unit.

Feed residues were weekly weighed in an electronic scale to calculate feed intake and feed conversion ratio per dozen eggs and per $\mathrm{kg}$ eggs. The number of eggs of each experimental unit was daily recorded in a dedicated form, and eggs were weekly weighed to obtain average egg weight. For egg quality analyses, 2 eggs per replicate were collected during 3 consecutive days every 28 days. These eggs were transported to the lab, and weighed in precision scale $(0.01 \mathrm{~g})$; their eggshell specific gravity was evaluated, and then broken to measure yolk and albumen percentages. Eggshells were dried in an oven at $60^{\circ} \mathrm{C}$ for three days, weighed and then eggshell percentage was calculated. Eggshell thickness was measured using a pachymeter in three different eggshell locations, and values were recorded in a dedicated form for subsequent calculation the final average. Haugh units were determined by measuring albumen height, using a micrometer, and calculation was based in the formula suggested by Stadelman \& Cotterill (1986):

\section{$\mathrm{UH}=100 \log \left(H+7.57-1.7 \mathrm{~W}^{0.37}\right)$}

Where $\mathrm{H}=$ albumen height $(\mathrm{mm}) ; \mathrm{W}=$ egg weight (g); 7.57 = correction factor for albumen height; and $1.7=$ correction factor for egg weight.

During rearing, development, and production stages, birds were fed diets based on corn and soybean meal, formulated according to NRC (1994) recommendation. Feed used during the production period is presented in Table 1. Experimental treatments, described in Table 2, consisted of different corn particle sizes (coarse and fine $-0.723 \mathrm{~mm}$ and $0.617 \mathrm{~mm}$, respectively) and limestone particle sizes (coarse, intermediate, and fine $-0.947 \mathrm{~mm}, 0.721 \mathrm{~mm}$, and $0.361 \mathrm{~mm}$, respectively), 
which were calculated according to Technical Communication 215 Embrapa - CNPSA (1996). The following performance parameters were analyzed: feed intake (FI), egg production (lay percentage), average egg weight, and feed conversion ratio per dozen eggs and per kg eggs. Analyzed egg quality parameters were: specific gravity, yolk and albumen percentages, and Haugh units.

\begin{tabular}{lc}
\hline Table 1 - Calculated percentage and chemical composition of \\
the experimental diet. \\
Ingredients & Quantity \\
Corn & 56.32 \\
Soybean meal & 33.32 \\
Soybean oil & 2.86 \\
Salt & 0.35 \\
Limestone & 5.35 \\
Dicalcium phosphate & 1.31 \\
Vitamin and mineral premix & 0.30 \\
DL-methionine & 0.14 \\
Choline (70\%) & 0.05 \\
Total & 100.00 \\
Nutrients & \\
Crude protein (\%) & 20.00 \\
Metabolizable energy (kcal/kg) & 2900 \\
Calcium (\%) & 2.50 \\
Available phosphorus (\%) & 0.35 \\
Methionine (\%) & 0.45 \\
Methionine + Cystine (\%) & 0.76 \\
Lysine (\%) & 1.07 \\
Choline (mg/kg) & 1564 \\
\hline *1 - Composition per kg experimental feed: Cu: 8 mg; Fe: 50 mg; \\
Mn: 70 mg; Zn: 50 mg; I: 1.2 mg; Se: 0.2 mg; 2 - Vit. A: 14,000 IU; vit. \\
D3: 4,000 IU; vit. E: 10 mg; vit. K3: 3.2 mg; vit. B2: $6 \mathrm{mg}$; vit. B12: 16 \\
mcg; Niacin: 40 mg; Pantothenic acid: 10 mg; Antioxidant: 30 mg. \\
\hline
\end{tabular}

Statistical analysis was performed using SISVAR statistical software, according to Ferreira (1998).
Performance and egg quality parameters were submitted to analysis of variance and means were compared by the test of Tukey at $5 \%$ significance.

\section{RESULTS AND DISCUSSION}

Performance results are presented in Table 3. There was no significant interaction between the studied factors (corn particle size vs. limestone particle size) relative to performance parameters.

The tested factors did not influence lay percentage, and $84.06 \%$ average lay percentage was obtained for the entire experimental period. These results are consistent with those of Leandro et al. (2001), who did not find significant effects of corn particle size on egg production of Japanese quails. Ito (2002) also did not observe any influence of limestone particle size on the egg production of 40-week-old light commercial layers.

Corn particle size did not affect $(p>0.05)$ cracked egg percentage, but limestone particle size had a significant effect $(p<0.05)$ on this characteristic. Fine limestone $(0.361 \mathrm{~mm}$ MGD) resulted in a higher percentage of cracked eggs, and was statistically different from coarse limestone (0.947mm MGD), which determined the lowest percentage of cracked eggs during the experimental period. Intermediate limestone particle size $(0.721 \mathrm{~mm}$ MGD) did not result in statistical differences as compared to the other particle sizes.

Egg weight was not significantly $(p>0.05)$ affected by corn or limestone particle sizes. These results are consistent with those observed by Deaton (1989), who

\begin{tabular}{|c|c|c|c|}
\hline Treatments & N. replicates & Birds/Repl. & Birds/Treat. \\
\hline 1- Fine corn feed with $100 \%$ fine limestone (T1) & 6 & 18 & 108 \\
\hline 2- Fine corn feed with $50 \%$ fine limestone and $50 \%$ intermediate limestone (T2) & 6 & 18 & 108 \\
\hline 3- Fine corn feed with $50 \%$ fine limestone and $50 \%$ coarse limestone (T3) & 6 & 18 & 108 \\
\hline 4- Coarse corn feed with $100 \%$ fine limestone (T4) & 6 & 18 & 108 \\
\hline 5- Coarse corn feed with $50 \%$ fine limestone and $50 \%$ intermediate limestone (T5) & 6 & 18 & 108 \\
\hline 6- Coarse corn feed with $50 \%$ fine limestone and $50 \%$ coarse limestone (T6) & 6 & 18 & 108 \\
\hline Total & 648 & & \\
\hline
\end{tabular}

\begin{tabular}{|c|c|c|c|c|c|c|c|}
\hline \multirow[t]{2}{*}{ Parameter } & \multicolumn{2}{|c|}{ Corn $(\mathrm{mm})$} & \multicolumn{3}{|c|}{ Limestone (mm) } & \multirow[t]{2}{*}{ CV (\%) } & \multirow[t]{2}{*}{ Mean } \\
\hline & 0.617 & 0.723 & $0.361 *$ & $0.721 * *$ & $0.947 * * *$ & & \\
\hline Lay (\%) & 83.52 & 84.59 & 82.22 & 85.37 & 84.58 & 4.95 & 84.06 \\
\hline Cracked (\%) & 1.28 & 1.24 & $1.40^{b}$ & $1.24^{\mathrm{ab}}$ & $1.14^{a}$ & 19.68 & 1.26 \\
\hline Egg weight (g) & 10.71 & 10.75 & 10.80 & 10.70 & 10.69 & 2.01 & 10.73 \\
\hline Egg mass (g/bird/day) & 8.96 & 9.10 & 8.89 & 9.15 & 9.05 & 5.08 & 9.03 \\
\hline Feed intake (g/bird/day) & 27.25 & 26.81 & 27.35 & 26.50 & 27.25 & 5.99 & 27.03 \\
\hline $\mathrm{FCR} / \mathrm{dz}$ & 0.40 & 0.39 & 0.41 & 0.38 & 0.39 & 10.66 & 0.39 \\
\hline $\mathrm{FCR} / \mathrm{kg}$ & 3.10 & 3.04 & 3.19 & 2.96 & 3.06 & 10.21 & 3.07 \\
\hline
\end{tabular}

* Diet with $100 \%$ fine limestone $(0.361 \mathrm{~mm}) * *$ Diet with $50 \%$ fine limestone $(0.361 \mathrm{~mm})$ and $50 \%$ intermediate limestone $(0.721 \mathrm{~mm}) * * *$ Diet with $50 \%$ fine limestone $(0.361 \mathrm{~mm})$ and $50 \%$ coarse limestone $(0.947 \mathrm{~mm})$. Means followed by different letters in the same row and within each factor are different by the test of Tukey $(P<0.05)$. 
fed layer chickens with feeds containing different corn particle sizes, and did not find any changes in egg size or quality. As to limestone particle size, Ito (2002) found that the use of coarse limestone (3.0 - $5.0 \mathrm{~mm} \mathrm{MGD)}$ in layer chicken feeds decreased egg weight as compared to feeds with fine limestone (MGD lower than $0.5 \mathrm{~mm}$ ) during the second experimental period. The contradiction with Ito's data is probably due to the different species used, to the limestone particle size range, or even to the lack of uniformity standardization (geometric standard diameter - GSD) in the analyzed particle sizes.

Average egg mass was $9.03 \mathrm{~g} / \mathrm{bird} / \mathrm{day}$. No significant effects of corn and limestone particle sizes on this parameter were verified.

Feed intake was stable during the entire experimental period, with an average of $27.03 \mathrm{~g} / \mathrm{bird} /$ day. No individual effects of different corn or limestone particle sizes were observed, which is consistent with data obtained by Deaton et al. (1989). However, the results of the present experiment are different from those of Magro et al. (1999), who observed that 21-2day-old broilers presented higher feed intake when fed corn particle sizes measuring $1.175 \mathrm{~mm}$ MGD.

No significant treatment effects $(p>0.05)$ were verified on feed conversion ratio by dozen eggs or by $\mathrm{kg}$ eggs. Average feed conversion ratio/dz was $0.39 \mathrm{~kg} /$ $\mathrm{dz}$, and average feed conversion ratio/kg eggs was $3.07 \mathrm{~kg} / \mathrm{kg}$. This lack of significant effects were also observed by Leandro et al. (2001) and Zanotto et al. (1999).

Data relative do internal and external egg quality parameters during the experimental period are presented in Table 4.

Average albumen percentage was $62.27 \%$. There was no interaction ( $p>0.05$ ) among the studied factors, nor significant effect of treatments on this parameter. These data are consistent with those reported by Deaton (1989) and Ito (2002), who showed that albumen percentage was not influenced by limestone particle size; however, they did not observe any interaction between corn and limestone particle sizes, which is different from the present study, where no interaction was found between analyzed factors (corn and limestone particle sizes) relative to albumen percentage.

When yolk percentage was analyzed, the results showed no significant interactions ( $p>0.05)$ among the studied factors, nor significant treatment effects on this parameter. Average yolk percentage was $29.48 \%$. These results are different from those obtained by Ito (2002), who observed that the effects of limestone particle size combined with corn particle sizes adversely influenced yolk percentage in all studied cycles.

No significant interaction ( $\mathrm{pP}>0.05$ ) was found between corn and limestone particle sizes, nor any treatment effect on eggshell percentage, eggshell thickness, or egg specific gravity. Average eggshell percentage, eggshell thickness, and egg specific gravity obtained during the experimental period were $8.25 \%$, $0.197 \mathrm{~mm}$, and $1.075 \mathrm{~g} / \mathrm{ml} \mathrm{H}_{2} \mathrm{O}$, respectively. The results of limestone particle size on eggshell quality parameters obtained in the present study are different from those of Guinotte \& Nys (1991b), who studied different combinations of calcium sources and particle sizes, and observed that calcium sources with particle sizes lower than $1.0 \mathrm{~mm}$ resulted in lower eggshell strength in commercial layer chickens. Roland's (1986) literature review on commercial layers also shows that calcium sources with particle sizes higher than $3.0 \mathrm{~mm}$ resulted in similar eggshell quality, independent of source (oyster meal or limestone). When only fine calcium sources are used, eggshell quality traits are worse. For instance, when commercial layers were fed calcium sources with particle sizes higher than $3.0 \mathrm{~mm}$, Scheideler (1998) obtained higher apparent eggshell density as compared with the use of calcium sources with particle sizes lower than $0.50 \mathrm{~mm}$.

The literature information mentioned above partially disagrees with the findings of the present study. Despite not detecting significant differences in specific gravity, eggshell percentage, or eggshell thickness

\begin{tabular}{|c|c|c|c|c|c|c|c|}
\hline \multirow[t]{2}{*}{ Parameter } & \multicolumn{2}{|c|}{ Corn $(\mathrm{mm})$} & \multicolumn{3}{|c|}{ Limestone $(\mathrm{mm})$} & \multirow[t]{2}{*}{ CV (\%) } & \multirow[t]{2}{*}{ Mean } \\
\hline & 0.617 & 0.723 & $0.361 *$ & 0.721 ** & $0.947 * * *$ & & \\
\hline Albumen (\%) & 62.24 & 62.30 & 62.12 & 62.22 & 62.48 & 1.04 & 62.27 \\
\hline Yolk (\%) & 29.52 & 29.43 & 29.64 & 29.57 & 29.23 & 2.14 & 29.48 \\
\hline Eggshell (\%) & 8.24 & 8.26 & 8.24 & 8.21 & 8.29 & 2.38 & 8.25 \\
\hline Eggs. thickn. (mm) & 0.196 & 0.198 & 0.197 & 0.196 & 0.197 & 2.86 & 0.197 \\
\hline Sp. gravity $\left(\mathrm{g} / \mathrm{ml} \mathrm{H}_{2} \mathrm{O}\right)$ & 1.075 & 1.075 & 1.074 & 1.075 & 1.075 & 0.15 & 1.075 \\
\hline Haugh units & 87.45 & 87.66 & 87.46 & 87.44 & 87.77 & 1.37 & 87.56 \\
\hline
\end{tabular}

* Diet with $100 \%$ fine limestone $(0.361 \mathrm{~mm}) * *$ Diet with $50 \%$ fine limestone $(0.361 \mathrm{~mm})$ and $50 \%$ intermediate limestone $(0.721 \mathrm{~mm}) * * *$ Diet with $50 \%$ fine limestone $(0.361 \mathrm{~mm})$ and $50 \%$ coarse limestone $(0.947 \mathrm{~mm}) .{ }^{1}(P>0.05)$. 


\section{Berto DA, Garcia EA, Móri C, Faitarone ABG, Pelícia K, Molino $A B$}

Performance of Japanese Quails Fed Feeds Containing Different Corn and Limestone Particle Sizes* among treatments as a function of limestone particle size, there was a numerical trend (not statistically significant) of specific gravity improvement when $50 \%$ intermediate or coarse limestone particle size was used, as compared to $100 \%$ fine limestone. On the other hand, a significant reduction in the percentage of cracked eggs was observed in birds fed $50 \%$ coarse limestone as compared to those fed only fine limestone. These results suggest that, although eggshell improvement, as measure by specific gravity, was not sufficient to be statistically detected $(p<0.05)$, it did improve eggshell quality, as demonstrated by the reduction of cracked egg percentage.

There was no treatment interaction, nor significant treatment effects ( $p>0.05)$ on Haugh units, which average was 87.56 in the present experiment. These results are different from those observed by Ito (2002), who observed interaction between limestone particle sizes and their ratios in the diet, as well as an isolated effect of limestone particle size on Haugh unit averages in light commercial egg layer eggs.

\section{CONCLUSIONS}

The use of different corn particle sizes $(0.617$ and $0.723 \mathrm{~mm}$ MGD) and limestone particle sizes (100\% $0.361 \mathrm{~mm} \mathrm{MGD;} 50 \% 0.721 \mathrm{MGD}$ and $50 \% 0.361$ MGD; $50 \% 0.947 \mathrm{~mm} \mathrm{MGD}$ and 50\% $0.361 \mathrm{~mm} \mathrm{MGD)}$ in the diet did not influence performance and egg quality parameters in the studied Japanese quails.

Considering the reduction of the percentage of cracked eggs with the use of $50 \%$ coarse limestone particle size $(0.947 \mathrm{~mm})$ as compared to birds fed only fine limestone particle size $(0.361 \mathrm{~mm})$, the use of $50 \%$ coarse limestone particle size $(0.947 \mathrm{~mm})$ can be recommended in the feed of Japanese quails for egg production.

\section{REFERENCES}

Coon NC. Feeding egg-type replacement pullets. In: Bell DD. Commercial chicken meat and egg production $5^{\text {th }}$ ed. Massachusetts: Kluwer Academic; 2002. p.287-393.

Deaton JW, Lott BD, Simmons JD. Hammer mill vs roller mill grinding of corn of commercial egg layers. Poultry Science 1989; 68(10): 1342-44.

De Brum PAR, Zanotto DL, Guidoni AL. Granulometria do milho em rações fareladas e trituradas para frangos de corte. Concórdla: Embrapa Suínos e Aves; 1998. (Instrução Técnica, 08).

Farmer M, Roland DA, Clarck AJ. Influence of dietary calcium on bone calcium utilization. Poultry Science 1986a; 65:337-344.

Ferreira DF. Programa Sisvar.exe: sistema de análises de variância. Versão 3.04. Lavras: UFLA; 1998.

Freitas HJ, Cotia JTB, Oliveira AIG. Grãos de milho inteiros e moídos na alimentação de frangos de corte. Revista de Ciência e Agrotecnologia, 26(6):1322-1329.

Guinotte F, Nys Y. Effects of particle size and origin of calcium sources on eggshell quality and bone mineralization in egg laying hens. Poultry Science 1991; 70:583-592.

Ito DT. Efeito do fracionamento de cálcio e granulometria do calcário sobre o desempenho e qualidade de ovos de poedeiras comerciais brancas [dissertação]. Pirassununga (SP): Universidade de São Paulo: 2002.

Klein $\mathrm{CH}$. Efeito da forma física da ração e do nível de energia da ração sobre o desempenho, a composição de carcaça e a eficiência de utilização da energia metabolizável consumida por frangos de corte [dissertação]. Porto Alegre (RS): Universidade Federal do Rio Grande do Sul; 1996.

Leandro NSM, Stringuini JH, Café MB, Orsine GF, Rocha AC. Efeito da granulometria do milho e farelo de soja sobre o desempenho de codornas japonesas. Revista Brasileira de Zootecnia 2001; 30(4):1266-1271

Magro N, Ribeiro AM, Penz Jr AM. Efeito da granulometria do milho no desempenho de frangos de corte no período de 21 a 42 dias de idade. $26^{a}$ Reunião da Sociedade Brasileira de Zootecnia; 1999; Porto Alegre, RS. Brasil.

Maiorka A. Efeito da forma física e do nível de energia da ração em dietas formuladas com base em aminoácidos totais e digestíveis sobre o desempenho e a composição de carcaça de frangos de corte, machos, dos 21 aos 42 dias de idade [dissertação]. Porto Alegre (RS): Universidade Federal do Rio Grande do Sul; 1998.

National Research Council - NRC. Nutrient requeriments of poultry. $9^{\text {th }}$ ed. Washington; 1994.

Roland SR DA. Eggshell quality. IV: oystershell versus limestone and the importante of particle size or solubility of calcium source. World Poultry Science Journal 1986; 42( 2):166-171.

Scheideler SE. Eggshell calcium effects o egg quality and calcium digestibility in first or third cycle laying hens. Journal Applied Poultry Research 1998; 7:69-74.

Zhang B, Coon C. The relationship of calcium intake, source, solubilty in vitro and in vivo and gizzard limestone retention in laying hens. Poultry Science, 76:1702-1706, 1997.

Zanotto DL, Guidoni AL, Brum PAR. Granulometria do milho em rações fareladas para frangos de corte. 36 Reunião Anual da Sociedade Brasileira de Zootecnia; 1999; Porto Alegre, RS. Brasil. p. 227.

Zanotto DL, Bellaver C. Método de determinação da granulometria de ingredientes para uso em rações de suínos e aves. Concórdia: Embrapa CNPSA; 1996. (Comunicado Técnico, 215). 